\title{
Teaching for Creativity Development: Lessons Learned from a Preliminary Study of Vietnamese and International Upper (High) Secondary School Teachers' Perceptions and Lesson Plans
}

\author{
Lieu Thi Bich Tran ${ }^{*}$, Nhat Thi Ho², Robert J. Hurle ${ }^{3}$ \\ ${ }^{1}$ Department of Educational Management, University of Education, Vietnam National University in Hanoi, \\ Hanoi, Vietnam \\ ${ }^{2}$ Department of Psychology and Education, Hanoi National University of Education, Hanoi, Vietnam \\ ${ }^{3}$ Independent Researcher, Burra, Australia \\ Email: "lieutran5@yahoo.com, tblieu.dhgd@moet.edu.vn,nhathothi@gmail.com,rob1940@gmail.com
}

Received 26 March 2016; accepted 22 May 2016; published 25 May 2016

Copyright (C) 2016 by authors and Scientific Research Publishing Inc.

This work is licensed under the Creative Commons Attribution International License (CC BY).

http://creativecommons.org/licenses/by/4.0/

(c) (i) Open Access

\section{Abstract}

This research explored Vietnamese and international upper secondary school teachers' perceptions and practices of teaching for creativity based on a preliminary analysis of 234 teachers' survey responses, 17 in-depth interviews, and 208 lesson plans. It was found that teachers had limited understanding about creativity and teaching for creativity. They focused more on creativity when it is required from policies and curriculum. They often used familiar and convenient creative tools. This research indicates that to enhance student creativity, teachers should be fully aware of creativity, teaching for creativity, required to develop and assess student creativity, and trained to use creative tools.

\section{Keywords}

Creativity, Creativity Development, Creative Skills, Creative Tools, Teaching for Creativity

\footnotetext{
${ }^{*}$ Corresponding author.
}

How to cite this paper: Tran, L. T. B., Ho, N. T., \& Hurle, R. J. (2016). Teaching for Creativity Development: Lessons Learned from a Preliminary Study of Vietnamese and International Upper (High) Secondary School Teachers' Perceptions and Lesson Plans. Creative Education, 7, 1024-1043. http://dx.doi.org/10.4236/ce.2016.77107 


\section{Introduction}

Creativity has become increasingly important in the twenty first century as creative and knowledge-based economies demand creative products that bring benefits and happiness to people. People with creative skills are a key resource for the development of these economies (Brady \& Edelman, 2012; Li, 2011). Educational thinkers and researchers believe that every individual has creative potential and education has a responsibility to nurture students' creativity (Ferrari, Cachia, \& Punie, 2009; Moran, 2010) to supply creative human resources for socioeconomic development both nationally and globally. A debate on a positive creativity as opposed to negative creativity has occurred in history and it draws more people’s attention nowadays (James \& Taylor, 2010). Negative creativity has become a people's focus when harmful products such as atomic bombs, terrorism, dishonest advertisements, crimes, harmful pesticides... have been produced that brought damages and sorrows to people and to society (Cropley, 2010; James \& Taylor, 2010). Negative as said, may also promote dishonesty (Gino \& Ariely, 2012). Teachers play a key role in developing creativity for students and they need to be aware of creativity, (both positive and negative) to educate their students to be happy, well rounded, well-adjusted creators who fit in well with their communities, giving and taking and contributing to others. They must have a wide domain and interdisciplinary knowledge as well as have the skills to teach for creativity. De Bono (1970) and Moran (2010) argued that to develop creative skills, one has to practice using creative tools and techniques. The role of creative tools was perceived as the biggest driver in increasing creativity (65\% globally, 76\% in the United States) in research of Brady \& Edelman (2012). In addition, it has been considered that schools should build creative environments for teachers and students to be creative (Moran, 2010; Starko, 2013) and policies, curriculum and, in particular, assessment for creativity should be deployed.

Research has found that creativity development in schools remains limited: curiosity, imagination and creative thinking have been separately and inadequately developed and being more focused in kindergarten and primary education than at upper education levels (Engel, 2013; Robinson, 2010; Sahlberg, 2009; Starko, 2013). There are many reasons for these limitations, including lack of resources and knowledge, lack of policies and curricula for creativity development, domination of traditional teaching methods, lack of creative tools, and narrow test-based assessment (Banaji et al., 2010; Brady \& Edelman, 2012; Moran, 2010).

As with many other countries around the world, Vietnam has recently increased its focus on creativity development in schools. In 2013, the Vietnamese Government promulgated a decision to reform its education system radically and comprehensively (MoET, 2013). Creativity development has become the central aim of this reform in order to develop individuals' creative potential. To facilitate the reform, the Ministry of Education and Training of Vietnam (MoET) built a draft new curriculum which embeds creativity in core competencies for Vietnamese students in the twenty-first century (MoET, 2015a). Although this reform is in line with current thinking and was long-awaited, developing teaching for creativity still gains little attention in schools. Teachers still focus on knowledge transmission and assessment by means of tests, rather than on creativity development and assessment.

In order to implement creativity development, especially for upper secondary school students, the education system needs to assess the reality of teaching for creativity in Vietnam and to learn from international experience. To undertake this assessment, theoretical concepts of creativity, and teaching for creativity, were discussed to form a theoretical framework for the study, in order to develop assessment tools, foster representation and discussion of findings, as well as provide suggestions for the implications of the study.

Therefore, the article begins with a discussion of theoretical concepts and then describes the methods used to gather and analyze data. The third section presents the main findings and discussions of how creativity and teaching for creativity are currently perceived by upper secondary teachers in Vietnam and internationally and how they have taught for creativity development. The final section summarizes and draws possible implications for teaching for creativity in general and for Vietnam in particular.

\section{Theoretical Concepts}

\subsection{Creativity and Conditions for Creativity Development}

Understandings of creativity are varied, but most researchers agree that creativity is a process of curiosity-exploring, imagining and thinking based on one's knowledge, experiences, emotions and motivations to generate original and effective (useful, fit, appropriate, or valuable) products (ideas, solutions and concrete objectives) 
(Runco et al., 2012; Sternberg, 1999; Vygotsky, 2004). Creativity in this positive meaning is an aim of a good education to grow our children as useful creators for society.

Different personal traits are needed for creativity (Gorny, 2007). However, curiosity, imagination and creative thinking are considered the important traits and they are closely interrelated in creative processes. Curiosity is one's strong desire to know how things work, how people think (Starko, 2013). It plays a pivotal role in the mental and intellectual improvement of a child, and makes the mind more active, and allows exploration of surroundings for new ideas (Barell, 2003). Imagination is the ability to create mental images or pictures; and the ability to be creative and to think of new, interesting ideas or methods that have not existed before (Hornby, 1995; Vygotsky, 2004). Imagination provides the foundation for creativity to arise (Brady \& Edelman, 2012) and the power to develop creative thinking (Li, 2011). Vygotsky (2004) contends that “the richer a person's experience, the richer is the material his imagination has access to" (p. 15). He elaborates that broadening one's experiences and allowing them to practice imaginative exercises making associations among real elements with fantasy and emotions through role playing, drawing and creative writing will help developing a creative imagination. Creative thinking is understood as high order thinking and is the art of generating solutions to problems by the force of imagination and reasoning (Okpara, 2007), and includes lateral thinking that allows people to see things in new and unusual ways (De Bono, 1970). In fact, development of a creative idea is a result of simultaneous processes of exploration, imagination and creative thinking and stimulated by individual emotions and motivations.

Curiosity, imagination and creative thinking play important roles in every creative domain. For example, in mathematics creativity means asking new questions, imagining different solutions and then choosing and using a unique one to solve a mathematical problem (Leikin, 2013; Nadjafikhaha, Yaftianb, \& Bakhshalizadehc, 2012). Jackson (2005) defines creativity in history as questioning and imagining about the past, using new approaches to analyze, explain and evaluate historical events, and making connections of the past to the present and the future. Other researchers claim that creativity in literature is typically shown by making new connections to form new words or new uses for old words, and by the use of creative writing tools and techniques to compose new poems, stories and novels. Researchers recommended that writers should have sensitivity in observations to explore lives and surrounding environments and abilities to combine different events or characteristics to imagine and create new characters or new details of a story (Larson, 2009; Maybin \& Swann, 2007; Ramet, 2007). In chemistry, creativity is characterized by the discoveries and the predictions of unknown chemical components, the imagination of new chemical structures, and by the inventions of new chemical compounds such as molecules, substances and chemical transformations (Committee on Challenges for the Chemical Sciences in the 21st Century, 2003). According to João and Silva (2013), creative thinking is essential for students in designing chemical products. It appears that every creative domain has its own creative products, but they all are underpinned by common processes of curiosity-exploration, imagination and creative thinking.

Creativity requires inputs of knowledge, creative skills and attitude towards creativity. There are several types of knowledge essential for creativity: knowledge about creativity, particularly its processes, specific professional and general cross-disciplinary knowledge:

Students require first of all a know-how of creativity, i.e. knowing how to think and how to perceive things in a different way, or how to make unforeseen and unexpected connections. Secondly, they will need some subject or domain-related knowledge in order to be creative in a particular area (Ferrari et al., 2009: p. 349).

Creative skill combines the sub-component skills of observing (Starko, 2013); imagining (such as visualizing and abstracting) (Meyer, 2012; Sorby, 1999); the skill of problem solving and use of technology (Moran, 2010), and thinking, especially lateral thinking (DeBono, 1970). To develop such skills, a person must focus on handson interaction with materials and ideas using diverse techniques and tools (DeBono, 1970; Moran, 2010).

Besides knowledge and skills, attitudes toward creativity: aesthetic concerns, feelings and emotions (both positive, e.g. happiness, pleasure, satisfaction, and negative, e.g. sorrow, depression, unhappy), and creative desire impact an individual's creativity (Fasko, 2001; Vygotsky, 2004). Further, creative environments (physical, social, and cultural) are an essential condition for creativity development. Such environments allow individuals to have opportunities to engage with clubs, information and communication technology (ICT), experiments, art, music and sport to carry out creative activities (Moran, 2010; Starko, 2013). A creative environment is also characterized by a special culture that encourages students to freely express their creative ideas (Vygotsky, 2004).

These explanations suggest that developing student creativity means equipping students with subject and cre- 
ative knowledge and skills, developing their curiosity, imagination, creative thinking and positive attitudes toward creativity and providing them creative environments to express their ideas.

Researchers suggest that to develop student creativity, teachers have to understand creativity and its implications for student development and obtain subject knowledge and creative skills themselves to teach for creativity. They need to be prepared for teaching for creativity in the processes of teacher training and re-training together with support from policies, curriculum and school environments (Banaji et al., 2010; Ferrari et al., 2009; Moran, 2010).

\subsection{Teaching for Creativity}

\subsubsection{Understanding of Teaching for Creativity}

Teaching for creativity means understanding and developing young people's creative abilities as well as encouraging them to believe in their creativity. It is a process of equipping them with knowledge about creative processes and providing opportunities for them to be creative by using hands-on activities and creative methods and tools (Moran, 2010; National Advisory Committee on Creative and Cultural Education (NACCCE), 1999). Teaching for creativity should always go together with assessment for students' creativity. Teachers should teach and assess what and how students "1) create, 2) invent, 3) discover, 4) imagine if..., 5) suppose that..., or 6) predict” (Sternberg, 2012: p. 8) and how their students' thinking is influenced, flexible, elaborate and original (Torrance, 1979).

The above discussions allow one to make conclusions that teaching for creativity requires teachers to: 1) believe in and develop students' personal abilities and positive attitudes toward creativity by equipping them with: a) knowledge of a particular discipline and related areas; b) knowledge about creativity; c) creative skills such as using creative methods and tools to explore, imagine and to think; 2) build creative classroom and school environments in which students can express their creativity. Teachers, in order to be successful in developing student creativity, have to understand their students' abilities and have wide subject and creative knowledge and skills, especially skills in using creative tools in their teaching. More importantly, teaching for creativity must be required and guided in policies and curricula and accompanied with assessments for students' creativity.

\subsubsection{Creative Tools/Techniques in Teaching for Creativity}

There is no consensus in understanding of the terms "tools" and "techniques" and they are usually used interchangeably in the literature. Hornby (1995) defines technique as methods of doing or performing something and a tool is anything that is used to do one's job or tasks. Researchers (Brady \& Edelman, 2012; De Bono, 1970; Vygotsky, 2004) use "creative tools" as the means for developing creativity. In this study, we use the term "creative tools", as it reflects means used in creative processes to undertake a creative task for producing creative products.

Many tools have been developed and used in teaching for different purposes. In creativity development, creative tools are used to foster creativity, especially creative thinking, imagination and curiosity. Each tool can be used to develop either specific or different competencies and at different creative phases (exploring, imagining and creative thinking) although a concrete creative phase often requires some specific tools.

Tools for Curiosity: includes questions such as five WHs (What? Who? When? Where? Why? and How), situations and exercises for children to explore their immediate environment; and scientific events for observation, exploratory games and physical activities to sense things (colors, shapes, and sounds) (Conklin, 2012; Dischler, 2010; Engel, 2013). Tools for curiosity are suggested for use at the beginning of creative processes to stimulate one's interest and inspiration in exploring new and special aspects and problems of things, tools which lay the foundations for imagination and creative thinking (Starko, 2013; Sternberg, 1999).

Tools for imagination: Language tools are considered the most powerful cultural tools for imagination development (Vygotsky, 2004). They consist of varied formats: creative writing, storytelling, questions, especially "What if?" and "Why not?", stories, fiction novels, dramatics, role play games (Fettes, 2010; Karwowski \& Soszynski, 2008; Vygotsky, 2004). Internet information, group interactions, according to Lehrer (2012), can help sparking imaginative ideas. Other tools include the Sensory Activation Model (SAM) (multi-sensory stimulation) (Algozzine \& Douville, 2004), random pictures and SCAMPER (S: Substitute; C: Combine; A: Adapt; M: Modify; P: Put to another use; E: Eliminate; and R: Reverse) (Eberle, 2005; Starko, 2013). Different creative tools are required for different cognitive components of a three stage model for imagination developed by Ho, Wang, \& 
Cheng (2013). These components include: 1) Brainstorming; 2) Association; 3) Transformation and Elaboration; and 4) Conceptualization, Organization, and Formation. Tools for imagination are recommended for use after the exploratory phase to develop new and different ideas and solutions (Starko, 2013; Vygotsky, 2004).

Tools for creative thinking: Starko (2013) recommends teachers use different tools developed by many authors in order to develop students' creative thinking: six thinking hats, questions, creative writing, problem solving, role play, brain storming, SCAMPER, provocations, random words (random inputs), metaphors and analogies and creative dramatics. Other authors have developed lateral thinking puzzles (Sloane, 2006) and Mindmap (Hyeler, 1996). Wiki, blog, social networks are also suggested for use in imaginative expression and collaboration for generating creative ideas (Northcott, Miliszewska, \& Dakich, 2007). Tools for creative thinking are usually used to select the best solution or idea, then modify and complete it and to create a creative product or solve a problem (De Bono, 1970; Starko, 2013).

As the development of imagination, curiosity and creative thinking differs by age, some of the tools are considered more popular and appropriate to upper secondary school students while the others require higher abstract thinking (Starko, 2013; Vygotsky, 2004). The description below details some common tools that can be used to develop different competencies and are appropriate to most upper secondary school students.

\begin{tabular}{|c|c|}
\hline Creative tools & Description \\
\hline A mind map & $\begin{array}{l}\text { A diagram used to generate ideas in general and new ones in creativity development. The concept is } \\
\text { written in the center and major ideas are connected to it while others branch out from those. Ideas can } \\
\text { be expressed by words, images or symbols or codes and must be colorful to describe associations of } \\
\text { ideas. Students are encouraged to create their own mind maps (Hyeler, 1996). }\end{array}$ \\
\hline Questions & $\begin{array}{l}\text { The five "Wh” questions, together with "How?” are used for exploration (Conklin, 2012) and } \\
\text { provocation of the mind to respond to issues and discover new things (Okpara, 2007). In particular, } \\
\text { "What if...” and "Why not?” are used for developing imagination (Starko, 2013). The use of creative } \\
\text { questions in the teaching and learning process will enrich the contextualization in the study tasks } \\
\text { (Neira \& Soto, 2013). }\end{array}$ \\
\hline SCAMPER & $\begin{array}{l}\text { This tool is used to develop the imagination or new products by adding or eliminating a part (or parts) } \\
\text { to modify an existing object or find new functions for it (Starko, 2013). }\end{array}$ \\
\hline Brainstorming & $\begin{array}{l}\text { helps generate ideas by individuals or groups. Each individual gives one idea in oral or written forms } \\
\text { and all ideas are accepted without critical comment (Starko, 2013). }\end{array}$ \\
\hline The six thinking hats & $\begin{array}{l}\text { are used to help a person find new perspectives and avoid becoming trapped in familiar patterns of } \\
\text { thought. The six color hats are used as follows: white focuses on information; green is for creative } \\
\text { efforts; red is for feelings, intuition, or emotion; black is for critical judgment; yellow is for benefits } \\
\text { and possibilities; and blue monitors the kinds of thinking being used. It is better to use these hats in } \\
\text { combination (Kivunja, 2015; Starko, 2013). }\end{array}$ \\
\hline Random word & $\begin{array}{l}\text { some random words are given and combined to make connections, form new meanings and } \\
\text { associations for generating creative and innovative ideas (Starko, 2013). }\end{array}$ \\
\hline A random picture & a tool for combining random pictures to form new images (Starko, 2013). \\
\hline Wiki \& Blog & $\begin{array}{l}\text { are software tools for social interactions that allow students to generate and spread new ideas to others } \\
\text { and to receive comments for accomplishing them (Northcott et al., 2007). }\end{array}$ \\
\hline
\end{tabular}

\section{Research Design}

\subsection{Research Questions and Objectives}

The following questions were raised in this study: 1) What do Vietnamese and international teachers at upper secondary schools understand about creativity and teaching for creativity? 2) How do they develop student creativity in their classrooms and what factors impact their practices?

Therefore, this research aims to investigate 1) perceptions of Vietnamese and international upper secondary school teachers on creativity, conditions for creativity development and teaching for creativity; 2) teachers' practices of teaching for creativity and factors impacting on their practices.

We used both quantitative and qualitative methods to collect data. A questionnaire was first administered, followed by in-depth interviews of teachers and lesson plans analysis together with school observations. 


\subsection{Population and Sample}

Vietnamese upper secondary schools comprise the last three grades of secondary education, levels 10 to 12 , which enrolls students at 15 to 18 years old. They are mainly mainstream, both public or private and located in urban, suburban/rural and mountainous areas of Northern, Central and Southern parts of the country.

UNESCO indicates creativity is an important indicator of education quality (Colclough, Packer, \& Movivans, 2004). Therefore, to become a quality school, the school should develop creativity for its students. By this meaning, we considered upper secondary schools offering a high quality of education are those which developed their students' creativity, and therefore, they were the subject of our research. Schools were selected through discussion with the City/Provincial Education and Training Departments using the following criteria: They should be: 1) mainstream schools; 2) offer a high quality of education (as ranked by the MoET and Education and Training Departments); 3) represent urban and suburban public, and private schools in each city/province. Based on the prescribed criteria, nine schools were selected: three in Hanoi in the North, three in Quangtri in the Central region and three in Ho Chi Minh City in the South. In each school, the principal was asked to randomly select 20 teachers covering 10 subjects to answer the survey. The survey with Vietnamese teachers was conducted in March and April 2015, before the new draft curriculum was released in August 2015. Overall, 180 teachers from these nine schools, the majority teaching Mathematics, Chemistry, Literature, and History were selected to answer the questionnaire and 163 of them responded. Of these respondents, 17 teachers who indicated that they knew more about creativity and creative tools than other participants were interviewed in depth. The sample is illustrated in Table 1.

As well as the formal survey, an online survey ${ }^{1}$ was sent to international secondary school teachers through their email address and via representatives of teacher networks for voluntary responses. However, only 71 teachers from different teaching contexts (13 from Thailand; 12 from India, 12 from Israel; 8 from South Africa; 7 US, 6 Australian and 13 other teachers) responded. Because the number of international teachers was so small, and the sample was self-selected, the information is not adequate for generalization and thus we used only some of their statements to compare to Vietnamese teachers about understanding teaching for creativity and the creative tools they used.

Together with surveys and interviews, 208 randomly chosen internet lesson plans in mathematics, chemistry, history and literature of Vietnamese, US and Australian teachers were analyzed in relation to analysis of that country's education curriculum and policies for creativity development. In Vietnam we analyzed 50 lesson plans created before the 2015-2016 school year and 50 others created during the 2015-2016 school year (the school year runs from September to June the next calendar year). These lesson plans had been developed by upper secondary school teachers in different provinces/cities and posted on the website giaoan.violet.vn. (the website is for teachers to share lesson plans and swap references for their teaching in Vietnam). In the US we analyzed 50 lesson plans in relation to the Common Core standards teachers posted on Share My Lesson at

http://www.sharemylesson.com/home.aspx which was developed by the American Federation of Teachers and TES (Teacher education society), and eight other lesson plans at

http://www.navystemfortheclassroom.com/lesson-plans by the Navy Stem organization. (STEM stands for Science, Technology, Engineering and Mathematics). Navy Stem is an organization that intends to develop students' capability in building the most awe-inspiring and unmanned vehicles and robotics which require a lot of creativity and imagination. We also analyzed 50 Australian teachers' lesson plans collected by TES Australia at www.tesaustralia.com/senior-secondary-teaching-resources.

\subsection{Data Collection Instruments}

Little research has been undertaken on creativity development at upper secondary school level, especially on

Table 1. Sample.

\begin{tabular}{cccc}
\hline Total & Hanoi (the north) & Quang Tri (central) & Ho Chi Minh (the south) \\
\hline $\begin{array}{c}\text { Number of selected schools (9) } \\
\text { Respondents (163) }\end{array}$ & 3 & 3 & 3 \\
\hline
\end{tabular}

${ }^{1}$ https://www.surveymonkey.com/r/X7VRW3Q. 
teachers' perceptions of teaching for creativity and their use of creative tools. Bunt (2009) conducted interviews with two South African teachers in an upper secondary school on their understanding of creativity in history; possibilities for creativity development in this subject; and teaching methods which they used. There was an online survey conducted by the European Commission for the European teachers at different educational levels and subjects (Cachia, Ferrari, Kearney et al., 2009). However, this survey focused mostly on their perceptions of whether creativity was a skill and could be developed in different subjects and in every person; especially the importance of ICT, extracurricular activities and curriculum for creativity to carry out creativity development for their students. This survey appeared not to cover all aspects of creativity and teaching for creativity as its focus was on ICT for creativity. The survey tools on teachers' perceptions of creativity and teaching for creativity should be developed fully according to definitions of creativity and teaching for creativity. Moreover, there was a lack of existing criteria for assessing lesson plans of teaching for creativity and therefore there is a need for developing such criteria to guide teachers in designing such lesson plans.

Due to limitations in the research on teaching for creativity development at upper secondary school level, we could not adapt instruments from previous studies, but developed our own. Our questionnaire was developed based on the theoretical concepts of creativity and teaching for creativity development to collect general data concerning teachers' understanding of creativity, conditions for creativity development and teaching for creativity. It began with an introduction about its purpose and collected some demographic information about the teachers (e.g., gender, teaching subject). The main body of the questionnaire consisted of items relating to teachers' perceptions of creativity, conditions for creativity development, teaching for creativity, focusing on knowledge and use of creative tools in teaching. Lists of definitions of creativity, conditions for creativity development, teaching for creativity and creative tools were provided for teachers to choose which they thought were appropriate. There were some intended omissions in the lists and a space after each question was provided for teachers to add their own understandings or list other tools they knew and used. To indicate their familiarity with creative tools, participants responded with “well known," "heard about,” or "totally don't know”. If they indicated that they knew a tool, they were asked to indicate how they had learned about it. To gain a sense of teachers' experience with tools, they responded with: “often use," “sometimes," “rarely,” or "never” (see Appendix 1 for an English-language translation of the questionnaire, which was originally administered in Vietnamese).

The questionnaire was first administered and based on the questionnaire data, in-depth interviews of teachers were followed to clarify teachers' perception of students' creativity; if they taught for creativity and reasons of why they taught, or did not, teach for creativity; why and how they used some creative tools or didn't use others even though they knew them well (see Appendix 2 for an English-language translation of the questions asked).

Teachers' lesson plans were analyzed to explore how teachers undertook their teaching for creativity. We analyzed creativity development in lesson plans according to teaching objectives (if teachers put creativity development in their teaching objectives), strategies of using creative tools and methods for creativity development. We assumed that teachers' perceptions and actions on teaching for creativity development were dependent on requirements and guidelines of policies and curricula. Therefore, education policies and curricula were studied to find their impacts on teachers' teaching for creativity development.

School observations were analyzed to enhance conclusions from the data. To observe the school environments, a standardized observation protocol was developed for use in each school which listed facilities and their use for students' creativity development. Classrooms, the surrounding environments, and laboratory facilities were photographed, described, and discussed with school leaders and teachers to see whether they were adequate and how they were used in teaching in general and for developing students' creativity in particular.

\subsection{Data Analysis}

For the questionnaire data, SPSS (20) was used to analyze the data from the teachers' answers. Teachers’ statements in the interviews were transcribed and then analyzed using a thematic approach (Simons, 2009). The major themes were formed to answer questions: why creativity development was or was not undertaken, how tools were used in different subjects, and why teachers often used or did not use creative tools in their teaching. Specific verbatim responses were used to illustrate the findings. Creativity development objectives, creative tools and methods teachers planned to use in their teaching were noted from the lesson plans. Education policies and the secondary education curricula were analyzed to see if creativity development objectives were required and embedded in curriculum content and subjects, and if teaching guidelines for teachers were provided. Finally, the 
photos, notes and discussions with the school leaders and teachers were analyzed to illustrate the conditions for students' creativity development. The data reliability was guaranteed by the triangulation of data collected from the paper and online surveys, careful capture of teachers' words in interviews, and lesson plan analysis, together with pictures taken and protocol observations.

\section{Results and Discussion}

\subsection{Creativity and Conditions for Creativity Development}

\subsubsection{Teachers' Perceptions of Creativity}

Most of the teachers agreed that developing creativity in students is important, and they mentioned creativity from different aspects, although many avoided any negative side. Data from the questionnaire and interviews revealed that almost all Vietnamese teachers highlighted creative products rather than creativity inputs and processes: e.g. $82 \%$ of them considered creativity as the production of new ideas; creativity as production of new solutions, a means of invention; and 57\% thought creativity was a process of making things better or newer. When teachers were more highly appreciative of creative products than creative processes, they would prevent students from taking the right steps towards creating a creative product: they may undermine exploration or imagination processes, and focus their students towards thinking of a new idea or a solution without allowing the students to try out different ideas or solutions before choosing the most creative way to solve a problem or the most creative idea to complete and implement it. Some international teachers appeared to have a better understanding of creativity. They saw it as processes of imagining, exploring and creative thinking:

Creativity is about building on the ideas of others or conceptually visualizing something new (an Australian teacher);

Thinking differently to generate new solution, ideas and things without having limitation of thinking (A Malaysian teacher)

It is important to teach students creativity not because we expect them to develop innovative products. Rather it helps to develop thinking processes and creates opportunities for students to draw connections and linkages between disparate subjects and disciplines. (A Singaporean teacher)

Teachers also had a tendency to misunderstand creativity. In the survey 5.6\% of Vietnamese teachers and 5.6\% (4 out of 71) of the international teachers considered "news" as creativity. Misunderstanding of creativity might lead to erroneous assumptions (Beghetto, 2005 quoted in Ferrari et al., 2009).

\subsubsection{Teachers' Perceptions of Conditions for Creativity Development}

Data analysis has showed that teachers' understanding about conditions for creativity was not comprehensive. They did not value subject and creativity knowledge as highly as creative competencies and they lacked knowledge about creative tools.

In particular, most Vietnamese teachers highlighted curiosity (82\%), imagination (71\%) and subject knowledge (70\%), followed by facilities (66\%) and encouraging environments $(60 \%)$ for creativity development. While aesthetic concern is considered a necessary motivation for creativity (Fasko, 2001), very few Vietnamese teachers (1.8\%) valued it. They added "love of beauty" as a necessary condition for creativity. Three teachers explained that love of beauty encourages people to create artistic and valuable things that benefit other people and society. "Love of beauty" stimulates the aesthetic sense, the understanding of the harmony of the physical elements, such as lines, shapes, sounds, colors and space that makes people feel joy and pleasure when exploring things and nature. Consequently, it stimulates people to create beautiful, harmonious and valuable things (Haynes, 1999). "Love of beauty", as the Vietnamese teachers understood, is opposed to the "dark side of creativity” as mentioned by researchers (Cropley, 2010; Gino \& Ariely, 2012; James \& Taylor, 2010) and this understanding would guide teachers in nurturing positive creativity for their students.

Vietnamese teachers' responses about conditions that facilitate creativity development appear in Table 2.

A majority of international teachers appreciated freedom and an encouraging environment supported creativity development, followed by subject knowledge. For example, one US teacher stated: "A respectful environment for unproven ideas to be shared and discussed among peers with instructional coach support". Similarly, an African teacher claimed that "children need to be given opportunities to tap into the creativity and explore it freely". 
Table 2. Teachers' perception of conditions for creativity $(n=163)$.

\begin{tabular}{cc}
\hline Conditions & Percent of teachers \\
\hline Having curiosity about surroundings & $82.2 \%$ \\
Having imaginative competence & $70.8 \%$ \\
Having knowledge about subjects & $70.2 \%$ \\
Having facilities for creative activities & $65.8 \%$ \\
Having encouraging environment for creativity & $60.2 \%$ \\
Understanding about creativity and its process & $51.6 \%$ \\
Having lateral thinking & $48.4 \%$ \\
Having freedom in teaching and learning & $16.1 \%$ \\
\hline
\end{tabular}

Other essential factors such as understanding about creativity and its processes and lateral thinking were not so well accepted by both Vietnamese and international teachers: only $52 \%$ of Vietnamese teachers and $38 \%$ of international teachers considered understanding about creativity and its processes to be important; $49 \%$ of Vietnamese teachers and 39\% of international teachers respectively thought lateral thinking facilitated creativity development. Fewer Vietnamese teachers considered the importance of freedom in teaching for creativity development (only 16\% valued this condition). This coincides with teachers' perceptions about creativity that highlighted creative products.

Vietnamese teachers considered facilities an important condition for teaching for creativity while international teachers emphasized them less. This is understandable as most Vietnamese schools lacked facilities. Observations of eight of the nine schools revealed that classrooms were narrow, and most schools had only one multimedia room and one or two computer rooms, despite large student numbers. Teachers said their schools could not afford facilities for students to practice with ICT and laboratory facilities. Starko (2013) indicates facilities help students to carry out creative activities. A lack of facilities in Vietnamese schools might impede students' participation in such activities.

However, some Vietnamese teachers considered sub-standard facilities not a key hindrance for their teaching for creativity. When interviewed, teachers of chemistry and physics explained that without laboratory facilities they could use online chemistry/physics experiments. This finding corresponds with a finding in Madan's research (2011), that Indian teachers successfully developed creativity for Indian children in poor conditions (they were seated on rugs and low stools to practice creative activities).

\subsection{Teaching for Creativity}

1) Teachers' perceptions of teaching for creativity

Teaching for creativity, as discussed above, requires teachers to understand and use creative methods and tools to develop students' creative competencies and skills, but teachers' understanding of teaching for creativity was insufficient. Only 35\% of Vietnamese teachers and 56\% of international teachers mentioned objectives for developing student creativity in teaching. In interviews, Vietnamese teachers appeared to have a weak belief in students' creativity, although they shared common explanations on the characteristics of students' creativity. They valued students' abilities to explore, imagine, think and solve problems in new ways. For example, chemistry teachers considered creative students as those who were able to predict what would happen in chemical reactions. Three literature teachers suggested students' creativity in their subject meant they understood new words, used new ways to understand a poem or novel, or wrote creatively. According to history teachers, creative students were those who could analyze and evaluate historical events from different perspectives and were able to imagine the past. However, all interviewed teachers concluded that creative students were rare. While teaching for creativity requires teachers to understand and encourage students to believe in their own creative ability, teachers' lack of belief in students' creativity would lead to neglect in teaching for creativity. Moreover, the teachers understood creativity only by its positive traits, as no teacher listed any negative traits of a creative student. Gorny (2007) considers many positive as well as different negative traits of a creative person, especially egotistical, impulsive, disordered, argumentative, and absentminded. When teachers could not understand the 
negative traits of creative students, they had a biased attitude toward these students, and in consequence, they would kill students' creativity. Therefore, to develop student creativity, teachers should know their students' both positive and negative creative traits.

Most Vietnamese and international teachers understood teaching for creativity as the use of creative methods, but use of creative tools was mentioned by only one Australian teacher. For example:

-Using creative projects to meet learning goals. For example, using Art in History class; including the best examples of creative work, providing freedom to create and assessing for creativity (two US teachers)

-The use of project based learning, teamwork, problem solving (Vietnamese teachers)

-Providing the tools and helping the students to think and work creatively (An Australian teacher)

Madan (2011) found that Indian teachers were successful in developing creativity for Indian students as they were taught the philosophy of creativity development, and they held a strong belief in students' creativity, they used experiential, hands-on learning and created contextually relevant, creative environments to develop their students' creativity. This suggests that more investigation of beliefs and understanding about creativity would be useful.

2) Teachers' use of creative tools

Most tools listed in this study were less well known and less used except for four tools: "five Wh" questions, "what if" questions, mind maps and Internet information by both Vietnamese and international teachers. In the sample schools, Mind maps were most widely used (81\% where a combined percentage for both "often" and "sometimes" was used). The five "Wh" questions were the second most widely used (75\%), followed by "what if' questions (54\%). Internet information was used by $44 \%$. However, the percentage of participants who indicated that they "often use" Internet information was higher than other tools. This is shown in Table 3 and Figure 1.

Table 3. The most well known tools and their use in teaching (in percentage) $(n=163)$.

\begin{tabular}{cccccc}
\hline \multirow{2}{*}{ Tools } & Well known & \multicolumn{3}{c}{ Frequency level } \\
\cline { 3 - 6 } & & Often & Sometimes & Rarely & Never \\
Mind map & 76.1 & 38.8 & 42.3 & 6.1 & 12.8 \\
Five WH questions & 62.5 & 38.0 & 37.4 & 8.0 & 5.5 \\
What if... question & 49.5 & 29.2 & 24.5 & 3.7 & 37.9 \\
Internet information & 65.8 & 44.4 & 3.1 & 6.1 & 46.3 \\
\hline
\end{tabular}

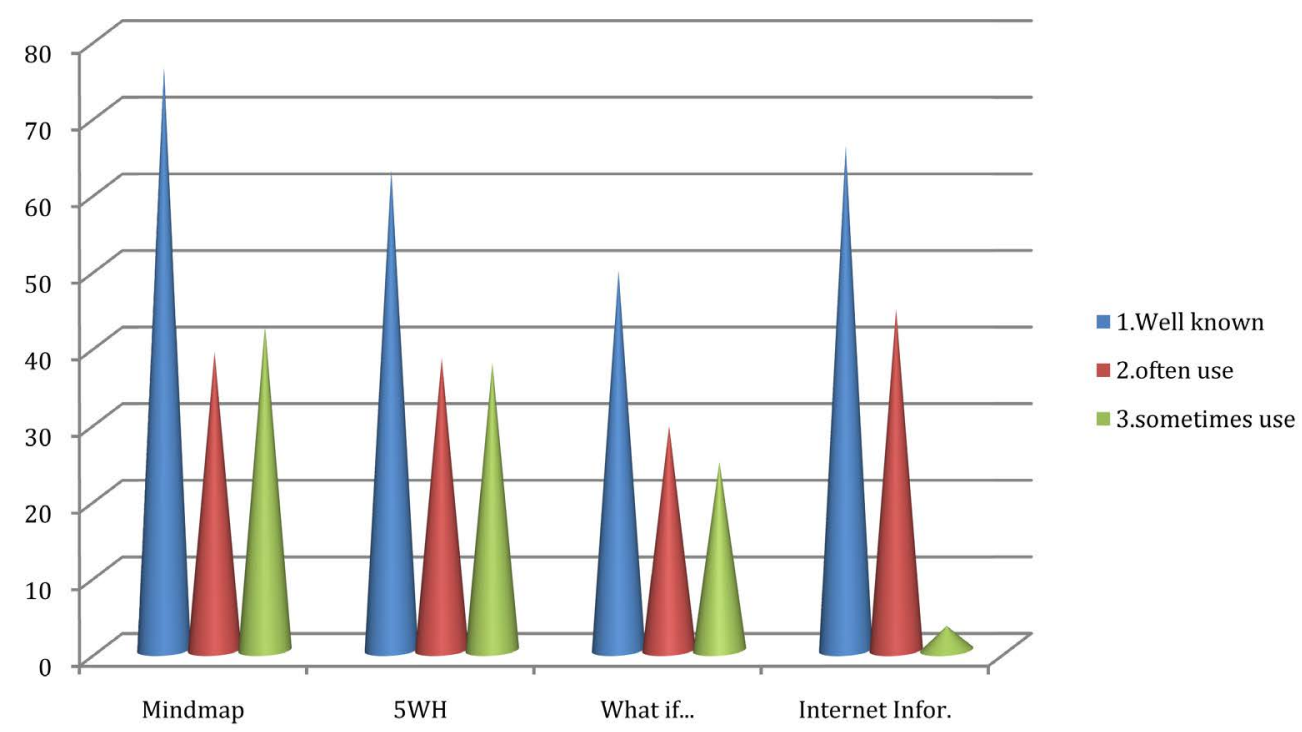

Figure 1. The most well known creative tools and their use in teaching in the Vietnamese upper secondary schools. 
Interviewed teachers explained that, questions were convenient because to use them teachers did not need to prepare or use specific teaching facilities. Teachers used questions with varying purposes. Some teachers stated that they used questions to provoke students' thinking and get their attention. "Questions help students to explore problems easily" (A chemistry teacher). Others revealed that they typically asked questions about facts more often than "why" questions. All interviewed teachers claimed they used questions combined with PowerPoint presentations or video clips, usually after watching videos. The use of questions was different across subjects. The five "Wh" and "What if..." questions were used more in mathematics, chemistry, physics and biology to help students guess results when changing variables in these fields. They featured less in literature as noted by a literature teacher:

I don't often use questions because they are not appropriate in all literature lessons. I don't want to break students' thoughts or emotions by asking many questions when they learn a poem or a story. Teaching and learning literature is a process in which teachers analyze, transform (the) emotion (or) ideas of a poem, novel or story to students through his/her words.

The statement shows that even though questions were considered a convenient creative tool, they were not frequently used by the teacher because of her conception of her teaching subject. Further, it reveals that the philosophy of knowledge transmission from teacher to students was still common in her mind.

Regarding mind map, most interviewed teachers stated that they usually used this tool to summarize students' knowledge. One mathematics teacher sometimes used mind maps to develop new knowledge for students, stating: "Sometimes I use (a) mind map in developing new knowledge. I put a new word in the center and ask questions to help students add relevant words to my word to learn new knowledge.” It can be seen that the teachers used mind maps, but not always for creativity development. In terms of the Internet, the teachers used it mostly to search for resources which helped to make learning more interesting. Only 22\% of teachers knew of Vi.wiki (Vietnamese wiki), and some of those teachers used Vi.wiki to look for new concepts and definitions. Blog was largely used for personal purposes rather than teaching.

A small number of teachers knew about tools for brainstorming, random picture, random word and the six thinking hats. From this group, an even smaller number actually used them, and they had mostly been selftaught. The percentage of teachers who "often use” SCAMPER was low (only 6.2\%, Table 4; Figure 2) across all subjects. Some literature teachers sometimes used SCAMPER when asking students to add or replace words in sentences and details of a story to form new endings. Of nine mathematics and chemistry teachers interviewed, only five focused on developing creative thinking by asking students to solve math or chemistry problems in new ways; to predict results when changing the variables in a calculation; or asking students to create poems or stories to learn formulas. Some other tools listed were: problems, short films, stories.

Similar to Vietnamese teachers, analysis of international teachers' responses and their lesson plans illustrate that they were well aware of the "five Wh" questions, "what if” questions, mind maps and Internet information and more often used them in teaching for creativity development. Blog and wiki also better known and used in teaching. International teachers were less familiar with random word, random picture and six thinking hats but they used them to a greater extent in their teaching. The least well known and less used was SCAMPER (4.2\% and 5.6\%), as with Vietnamese teachers.

Vietnamese teachers had limited use of creative tools and used them mainly for knowledge transmission, for many reasons. It is probable that the first reason is their limited understanding and skills in using such tools.

Table 4. The less well known tools and their use in the teaching (in percentage) $(n=163)$.

\begin{tabular}{cccccc}
\hline \multirow{2}{*}{ Tool } & Well known & \multicolumn{3}{c}{ Frequency level } \\
\cline { 3 - 6 } & & Often & Sometimes & Rarely & Never \\
\hline SCAMPER & 14.2 & 6.2 & 1.8 & 0.6 & 93.4 \\
Random picture & 33.3 & 8.4 & 0 & 9.2 & 82.4 \\
Six thinking hats & 15.3 & 10.3 & 16.6 & 9.2 & 63.9 \\
Brainstorming & 38.8 & 14.7 & 16.0 & 0 & 69.3 \\
Random word & 43.3 & 17.7 & 17.2 & 7.4 & 57.7 \\
\hline
\end{tabular}




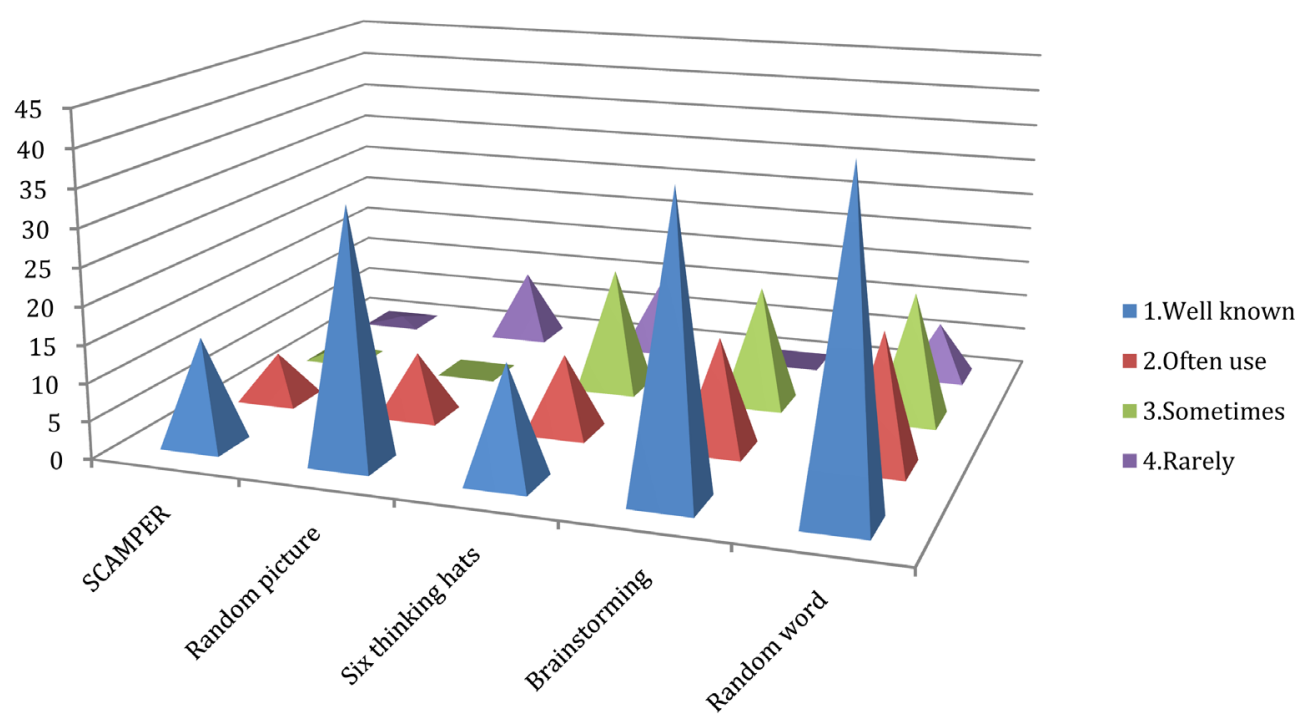

Figure 2. Less well known creative tools and their use in teaching in the Vietnamese upper secondary schools.

Most of them reported that SCAMPER and six thinking hats were complicated to use. Teachers use tools that are convenient for them and that they have enough understanding of them. Their practices of teaching for creativity are aligned with the current curriculum, requiring the provision of only knowledge and basic skills for students. Further, teachers claimed that the use of the tools often required more time and effort, while a standard Vietnamese lesson of 45 minutes was considered too short for using them.

Generally, teachers lacked understanding of ICT and other creative tools. They thought teaching for creativity meant using ICT to help students learn actively and easily. Their explanations were correct, but not sufficient when ICT is one of the very powerful tools for creativity development (Ferrari et al., 2009).

3) Factors impacting on the practice of teaching for creativity

a) Requirements and assessment for creativity development

Teachers' lesson plans and their responses from survey and interviews reveal that requirements for creativity development and assessment play vital roles in teaching for creativity. For example, a requirement for creativity development and understanding its importance for students motivates teachers to teach for creativity. South Africa's teachers said they taught for creativity development because it was a part of the curriculum and necessary for entrepreneurship, creative thinking and innovation, and solving unseen problems. A US and an Indian teacher taught for creativity because they thought creativity was necessary for students to be successful in their future jobs and a Japanese teacher said, it helped students learn in a constructive way. In fact, creativity development has been required in these countries for decades (National Council of Educational Research and Training, 1998; P21, 2007; Tan, 1997).

However, understanding about creativity and its importance alone, without curriculum and assessment requirements for creativity, does not necessarily lead to teaching for creativity. Although Vietnamese teachers understood the importance of creativity and even where schools had good teaching facilities, they did not teach for creativity because of no requirements from the curriculum and a strict culture of test-based assessment. For example, one private school in this study had invested in facilities for developing students' talent in music, dance, art, information technology and sport. It also offered meals for students so they could stay all day to take part in these extra activities. Tables and chairs in classrooms were convenient for group work and for students to move around easily. However, creativity development was not the focus there. The principal of that private school said that as Vietnam participated in the Program for International Student Assessment (PISA), her school was focused on teaching students to pass tests like this. Likewise, thirteen of seventeen interviewed Vietnamese teachers explained that they did not teach for creativity because parents and MoET required them to focus only on knowledge and testing skills to enhance students' exam scores. In fact, the current Vietnamese curriculum (MoET, 2006) does not require schools to develop creativity, but focuses more on basic knowledge and skills in separate subjects. Evaluation of education quality of schools is based on students' scores for academic and uni- 
versity entrance exams and strict knowledge-based tests have been widely used in almost all subjects, even in the 2014-2015 national high school exams (MoET, 2015b). In addition, parents' expectation on creativity development also impacted on teachers' practice. The principal of that private school also explained that they could not focus on creativity because parents would blame the school if their children did, or thought of, something unusual. Before 2013, there were almost no policies for creativity development in education and no documents that guided teachers in developing student creativity. Creativity development has progressed in the Vietnamese teachers' lesson plans ${ }^{2}$ since the promulgation of a radical and comprehensive education reform in 2013, and increased after the release of the new draft curriculum in August 2105 that requires creativity development for students. Math lesson plans (geometry and algebra) which focused on creativity development slightly progressed from three out of 20 before the 2015-2016 school year to five of the 20 created in 2015-2016. All of these eight lesson plans asked students to solve math problems using different solutions. Only one of the latter five aimed to develop imagination and required students to use teamwork, discussion and real life problems to solve math problems. Only one of 10 chemistry lesson plans created before 2015-2016 had a teaching objective which expected students to explore and solve problems by new procedures, without mentioning any creative tools and creative activities to implement the objective. In 2015-2016, three out of 10 focused on developing students' creative thinking and skills of observing, doing experiments, and undertaking scientific research. Use of tools such as problems, questions, mind-maps, and models were planned. Two of 10 lesson plans in literature created in 2015-2016 had the objective of developing creative thinking but none of 10 before 2015-2016 had. Most literature lesson plans gave students questions to explore creative writing techniques and some required creative writing. No history lesson plans focused on creativity development even after 2015. History is not a core subject in Vietnam's education, therefore, it is under taught and learned.

Although some progress in teaching for creativity has been made, there has still been no specific guidance for teachers about how to teach for creativity in Vietnam. Teachers therefore, continue to face difficulties in understanding and implementing teaching for creativity. Vietnamese classes still lacked both creative teaching and assessment. Vietnam's situation is similar to that in some other places in South Africa, the US, Hong Kong and Europe in the early 2000s, in that their teachers deployed mostly traditional teaching methods and testing assessment. Researchers suggest that teaching and assessing for creativity should always go together and should be focused on the development of students' creative competencies and evaluation of their creative products (Fasko, 2001; Sternberg, 2012; Torrance, 1979).

The impacts of curriculum and policies for creativity development can be found in teachers' lesson plans in other countries. In the US, policies have been developed to boost creativity in technology, natural and social sciences, and cultural fields (Committee on Prospering in the Global Economy of the 21st Century, 2010; National Endowment for the Arts, 2010) to meet the 21st Century citizenship standards where creativity and innovation development is a priority (P21, 2007). However, Common Core Standards (Council of Chief State School Officers (CCSSO) and the National Governors Association (NGA), 2016) which require teachers to provide basic knowledge and skills for students for their college or career success, have been also been simultaneously implemented. Therefore, the US teachers' lesson plans are designed to meet Common Core Standards as well as the creativity development requirement. In the 50 reviewed lesson plans which were created on Share My Les$s^{3}{ }^{3}$, in addition to planned basic and knowledge skills, a variety of learning activities using different creative tools such as questions, creative writing, and random words were included in order to develop students' curiosity, creative thinking and imagination although creativity development was not explicitly stated in teaching objectives. Most of the 20 reviewed math lesson plans required use of questions for students to explore math concepts and to imagine: "In your brain, write or draw everything you can remember about calculating the area of a parallelogram?”. Students were expected to apply knowledge of equations, quadrilaterals and transformations to design a city and explain how geometry is used. Similarly, analysis of 10 chemistry lesson plans reveals that students were encouraged to develop curiosity, imagination, and creative thinking: "Can you picture what you would see happening in an experiment?", "Use your own mind-map to summarize what you have learned"; "Test colored flower petals with acids and bases". In 10 language and literature lesson plans, teachers planned to use creative writing, creating new words, exploring authors' writing techniques, and questions. There were plenty of creativity assignments in 10 history lesson plans, such as "make a poster, poem or diary to illustrate historical events", or questions like "Can you imagine yourself 'declaring independence'? From what, and

\footnotetext{
${ }^{2}$ giaoan.violet.vn.

${ }^{3}$ http://www.sharemylesson.com/home.aspx.
} 
why?”, “Imagine yourself in Philadelphia in July 1776”, etc. Additional internet resources were used in almost all lesson plans. Likewise, in lesson plans created by the Navy Stem program ${ }^{4}$ different creative tools and hands-on activities, especially modern technological tools were used to develop student creativity meeting the requirements of creativity in the professions needed in the Navy.

In Australia, the curriculum (Australian Curriculum Assessment and Reporting Authority, 2013) requires the development of critical and creative thinking for students. Students are expected to use curiosity and imagination, and then critical and creative thinking to generate new ideas and apply knowledge to new contexts. Schools use games, real life contexts, problem solving and inquiry teaching, project and topic-based learning to train teachers to teach students ${ }^{5}$ and in lesson plans updated from June $2013^{6}$. However, many lesson plans created before 2013 focused only on basic knowledge and skills. Tytler (2007) reasoned that traditional teaching methods and knowledge content led to a crisis in students' learning of science and he stated that only a competence based curriculum reform would solve this crisis in Australia.

Knowledge transmission and test-based assessment which were common in Vietnamese schools discouraged teachers to teach for creativity. Practices of teaching for creativity have faced a number of challenges in many countries. Research conducted in Hong Kong and South African schools found that although creativity was included in national curriculum objectives, teaching for creativity still poses practical challenges, including lack of resources, test-based assessment and teachers' limited knowledge and teaching experience with creativity (Bunt, 2009; Cheng, 2004).

b) Teacher training on use of creative tools

Research has found that training teachers in how to use creative tools is the key for creativity development (Brady \& Edelman, 2012; Starko, 2013). Around 70\% of Vietnamese teachers stated they have been taught the four tools (questions, mindmap, "what if" question and internet information) and they used them in their teaching more than others. Brady and Edelman (2012) found lack of creative tools and training to use them prevented people from creativity. Training teachers in the use of creative tools has proven important, as Starko (2013) found, that tools are insufficient without training in when and how to use them, and under what circumstances they might be useful.

\subsection{Conclusions and Implications}

Generally, both Vietnamese and international teachers in this research appeared not to have a comprehensive understanding of creativity and conditions for creativity development as well as teaching for creativity development. Particularly, they did not highlight the importance of understanding about creativity and its processes for creativity development. Teachers paid more attention on teaching for creativity when they are pushed by policies and curriculum. They tended to apply some creative tools that they felt familiar with and which were convenient to use.

However, differences existed in perceptions and practices of teaching for creativity between Vietnamese and international teachers. International teachers tended to understand creativity better and used creative tools more in their teaching. A few international teachers had a better understanding about creativity, since they saw creativity not only as creative products, but also its processes. Accordingly, international teachers used a variety of creative tools to develop students' curiosity, imagination, and creative thinking. In contrast, most Vietnamese teachers used creative tools mainly for knowledge transmission. Moreover, there is a difference between teachers' "knowing" and "doing" in the nine sample schools. Teachers valued the importance of creativity, but they did not teach for creativity. In particular, although they considered curiosity, imagination, and creative thinking as important creative competencies, they did not include the objective of developing such competencies into their lesson plans and teaching. This may also be a result of the teachers' lack in understanding creative

\footnotetext{
${ }^{4}$ http://www.navystemfortheclassroom.com/lesson-plans.

${ }^{5}$ Illustrations of Practice, a showcase of teaching practice from across Australia.

${ }^{6}$ http://www.aitsl.edu.au/australian-professional-standards-for-teachers/resources/topics/maths-and-science\#03

$\checkmark \quad$ www.tesaustralia.com/senior-secondary-teaching-resources/ Real Life Mean Median Mode and Range: https://www.tes.com/teaching-resource/real-life-mean-median-mode-and-range-6296261 Matchstick problems-Thinking Skills Activity. Game: https://www.tes.com/teaching-resource/matchstick-problems-thinking-skills-activity-game-6029665

$\checkmark$ Write a mathematical nursery rhyme or poem: https://www.tes.com/teaching-resource/write-a-mathematical-nursery-rhyme-or-poem-6262550

$\checkmark$ History lesson plans teach students investigate skills at: http://www.tesaustralia.com/modern-history-senior-secondary-teaching-resources/
} 
processes. Test-based assessment still dominates in Vietnamese schools, while the new draft curriculum requiring teaching for creativity is only in the initial stages of experimentation. For this reason, teaching for creativity is not common in teachers' practices. It was evident in these nine schools which are considered having "good quality education”, yet teachers rarely or never taught for creativity.

Requirements for creativity development and teacher preparation are key factors that impact on teaching for creativity. Teaching for creativity increases when creativity development for students is put into policies and curriculum such as in Vietnam, Australia, and US or is required by a particular professional domain as in the US Navy.

As this study was conducted with a modest population, a larger sample and a more systematic study regarding perceptions and practices of teaching for creativity and conditions for creativity development are needed to give a more detailed and broader picture of teaching for creativity in different upper secondary school types in Vietnam, as well as internationally. Data about teaching for creativity across different educational levels: the impact of the curriculum, especially the new one in Vietnam, on practices of teaching for creativity should be further studied.

Our research is significant as it highlights the importance and a close relation between creativity awareness and requirements for creativity development. It also reinforces the previous findings that teacher preparation is a key for creativity development and that domination of test-based assessment is a big obstacle for creativity development globally. Researchers (Banaji et al., 2010; Brady \& Edelman, 2012; Bunt, 2009; Cheng, 2004; Ferrari et al., 2009) recommend that a combination of teacher preparation, policies, curricula, environments and assessment for creativity is to be carried out for student creativity development. Further, our study found that teachers' understanding about creativity and creative tools was limited, and not enough attention has been paid to results from previous research. As a result, this study draws some lessons to make teaching for creativity more successful:

1) Policies and education curricula for creativity development are preliminary and necessary conditions, and they should require, as well as guide, teachers to develop and assess student creativity.

2) Development of creative competencies is important for students; therefore, teachers should put development of students' creative competencies in their teaching objectives parallel with a design of appropriate learning activities, using appropriate creative tools and assessment to implement the objectives, and guide students to know-how of creativity. This requires teachers with creative competencies and a full awareness of creativity, its different aspects, including positive and negative; therefore they have to be adequately prepared.

3) When teachers are equipped with knowledge about creativity, creative tools, and teaching methods, they will find ways to implement creativity development objectives, e.g., teachers can use what is available around them such as nature, everyday life contexts, and internet resources to develop students' creativity. For this reason, creative tools should be made available in the curriculum and other teachers' documents and teachers should be guided in how to use them in teaching for creativity.

4) It is important that assessment should be focused on assessing students' creativity and should replace existing testing assessment methods.

5) Aesthetic concern is important for creativity, and therefore, teachers should be required to focus on educating the aesthetic sense for students in order to help them to create beautiful and valuable things.

Creativity development in general faces challenges, lags behind the theory and the real demands of economic and social developments almost everywhere, especially in Vietnam. To foster creativity development, a country should first develop policies and curricula for creativity in which creativity development objectives are required and guidelines for teaching and assessing creativity are formulated. Schools should have adequate creative environments and should give teachers freedom and encourage them to find new ways to implement creativity development objectives. Teachers should be trained how to use creative tools and methods. For developing countries like Vietnam, facilities can be provided after solid teacher preparation. In the digital age, it is important to guide teachers to use internet resources if schools cannot afford teaching facilities for them.

Developing creativity in Vietnamese schools appears to be far away compared to other countries. This preliminary study provides some useful lessons for creativity development in general, and for Vietnam in particular, to narrow the gap.

\section{Acknowledgements}

This research was funded by the Vietnam National Foundation for Science and Technology Development 
(NAFOSTED) grant number VI2.2-2013.16.

\section{References}

Algozzine, B., \& Douville, P. (2004). Use Mental Imagery across the Curriculum. Preventing School Failure: Alternative Education for Children and Youth, 49, 36-39. http://dx.doi.org/10.3200/PSFL.49.1.36

Australian Curriculum Assessment and Reporting Authority (2013). Curriculum Design Paper. Version 3.1. http://www.acara.edu.au/verve/_resources/07_04_Curriculum_Design_Paper_version_3+1_\%28June_2012\%29.pdf

Banaji, S., Cranmer, S., \& Perrotta, C. (2010). Expert Perspectives on Creativity and Innovation in European Schools and Teacher Training. Luxembourg: European Commission Joint Research Centre Institute for Prospective Technological Studies. http://ftp.jrc.es/EURdoc/JRC59833 TN.pdf

Barell, J. (2003). Developing More Curious Mind. Alexandria: Association for Supervision and Curriculum Development (ASCD).

Brady, R., \& Edelman, L. A. (2012). State of Create Global Benchmark Study: Global Benchmark Study on Attitudes and Beliefs about Creativity at Work, School and Home. https://www.adobe.com/aboutadobe/pressroom/pdfs/Adobe_State_of_Create_Global_Benchmark_Study.pdf

Bunt, B. (2009). The Nurturing of Creativity in the History Classroom through Teaching Methods—The Views of Teachers and Learners. Yesterday \& Today, 4, 107-124. http://dspace.nwu.ac.za/handle/10394/5517

Cachia, R., Ferrari, A., Kearney, C., Punie, Y. et al. (2009). Creativity in Schools in Europe: A Survey of Teachers. European Commission, Joint Research Centre, Institute for Prospective Technological Studies. http://ftp.jrc.es/EURdoc/JRC55645_Creativity\%20Survey\%20Brochure.pdf

Cheng, V. M. Y. (2004). Developing Physics Learning Activities for Fostering Student Creativity in Hong Kong Context. Asia-Pacific Forum on Learning and Teaching, 5, 1-33. https://www.ied.edu.hk/apfslt/v5_issue2/chengmy/

Colclough, C., Packer, S., \& Movivans, A. (2004). Education for All: The Quality Imperative. EFA Global Monitoring Report 2005. Paris: UNESCO Publishing. http://unesdoc.unesco.org/images/0013/001373/137333e.pdf

Committee on Challenges for the Chemical Sciences in the 21st Century (2003). Beyond the Molecular Frontier: Challenges for Chemistry and Chemical Engineering. Washington DC: The National Academies Press.

Committee on Prospering in the Global Economy of the 21st Century (2010). Rising above the Gathering Storm: Energizing and Employing America for a Brighter Economic Future. Washington DC: National Academy Press.

Conklin, W. (2012). Strategies for Developing Higher-Order Thinking Skills, Grades 6-12. Huntington Beach, CA: Shell Educational Publishing.

Council of Chief State School Officers (CCSSO) and the National Governors Association (NGA) (2016). Common Core State Standards Initiative. http://www.corestandards.org/about-the-standards/

Cropley, J. A. (2010). The Dark Sides of Creativity: What Is It? In H. D. Cropley, J. A. Cropley, J. C. Caufman, \& A. M. Runco (Eds.), The Dark Sides of Creativity (pp. 1-14). Cambridge: Cambridge University Press.

http://dx.doi.org/10.1017/cbo9780511761225.001

De Bono, E. (1970). Lateral Thinking: Creativity Step by Step. New York: Harper \& Row.

Dischler, P. A. (2010). Teaching the 3 Cs: Creativity, Curiosity, and Courtesy: Activities That Build a Foundation for success. Thousand Oaks, CA: Sage Company.

Eberle, B. (2005). Scamper: Creative Games and Activities for Imagination Development. TX: Prufrock Press.

Engel, S. (2013). The Case for Curiosity. Educational Leadership, 70, 36-40.

Fasko, D. (2001). Education and Creativity. Creativity Research Journal, 13, 317-327. http://dx.doi.org/10.1207/S15326934CRJ1334_09

Ferrari, A., Cachia, R., \& Punie, Y. (2009). ICT as a Driver for Creative Learning and Innovative Teaching. In E. Villalba (Ed.), Measuring Creativity (pp. 345-367). Luxemburg: OPOCE.

Fettes, M. (2010). The Ties That Bind: How Imagination Grasps the World. In K. Egan, \& K. Madej (Eds.), Engaging Imagination and Developing Creativity in Education (pp. 2-16). Newcastle upon Tyne: Cambridge Scholars Publishing.

Gino, F., \& Ariely, D. (2012). The Dark Side of Creativity: Original Thinkers Can Be More Dishonest. Journal of Personality and Social Psychology, 102, 445-459. http://dx.doi.org/10.1037/a0026406

Gorny, E. (2007). Creative Person. In Dictionary of Creativity: Terms, Concepts, Theories \& Findings in Creativity Research. Netslova.ru. http://creativity.netslova.ru/Creative_person.html

Haynes, F. (1999). Aesthetic Education. In M. A. Peters, \& P. Ghiraldelli Jr. (Eds.), Encyclopaedia of Philosophy of Education. http://eepat.net/doku.php?id=aesthetic_education 
Ho, H. C., Wang, C. C., \& Cheng, Y. Y. (2013). Analysis of the Scientific Imagination Process. Thinking Skills and Creativity, 10, 68-78. http://dx.doi.org/10.1016/j.tsc.2013.04.003

Hornby, A. S. (1995). Oxford Advanced Learner's Dictionary. Oxford: Oxford University Press.

Hyeler, D. (1996). Visual tools for Constructing Knowledge. Alexandria, VA: ASCD

Jackson, N. (2005). Creativity in History Teaching and Learning. Subject Perspectives on Creativity in Higher Education Working Paper, Portsmouth: University of Portsmouth.

James, K., \& Taylor, A. (2010). Positive Creativity and Negative Creativity (and Unintended Consequences). In H. D. Cropley, J. A. Cropley, J. C. Caufman, \& A. M. Runco (Eds.), The Dark Sides of Creativity (pp. 33-56). Cambridge: Cambridge University Press. http://dx.doi.org/10.1017/CBO9780511761225.003

João, I. M., \& Silva, J. M. (2013). Creative Thinking in Chemical Product and Process Design Education. 1st International Conference of the Portuguese Society for Engineering Education (CISPEE), Portugal, 31 October-1 November 2013, 1-6. http://dx.doi.org/10.1109/CISPEE.2013.6701961

Karwowski, M., \& Soszynski, M. (2008). How to Develop Creative Imagination? Assumptions, Aims and Effectiveness of Role Play Training in Creativity (RPTC). Thinking Skills and Creativity, 3, 163-171. http://www.elsevier.com http://dx.doi.org/10.1016/j.tsc.2008.07.001

Kivunja, C. (2015). Using De Bono’s Six Thinking Hats Model to Teach Critical Thinking and Problem Solving Skills Essential for Success in the 21st Century Economy. Creative Education, 6, 380-391. http://dx.doi.org/10.4236/ce.2015.63037

Larson, A. (2009). Literary Creativity. In B. Kerr (Ed.), Encyclopedia of Giftedness, Creativity, and Talent. Thousand Oaks, CA: Sage Publications. http://dx.doi.org/10.4135/9781412971959.n233

Lehrer, J. (2012). Imagine: How Creativity Works. Boston, MA: Houghton Mifflin Harcourt

Leikin, R. (2013). Evaluating Mathematical Creativity: The Interplay between Multiplicity and Insight. Psychological Test and Assessment Modeling, 55, 385-400.

Li, W. W. (2011). How Creativity Is Changing China. London: Bloomsbury Academic.

Madan, A. (2011). Creativity Education in India: Breaking Barriers, Three Case Vignettes. https://www.inter-disciplinary.net/wp-content/uploads/2011/06/madancpaper.pdf

Maybin, J., \& Swann, J. (2007). Everyday Creativity in Language: Textuality, Contextuality, and Critique. Applied Linguistics, 28, 497-517. http://dx.doi.org/10.1093/applin/amm036

Meyer, K. (2012). Imagination in Learning Electrical Physics. Doctoral Thesis, Australia: Charles Sturt University.

MoET (2006). Chuong trinh giao duc pho thongtrung hoc [Secondary Education Curriculum]. Hanoi.

MoET (2013). Nghi quyet 29 ve Doi moi co ban, toan dien giao duc Vietnam [Resolution No. 29 on Radical and Comprehensive Reform of Education and Training]. Hanoi.

MoET (2015a). Du thao chuong trinh giao duc pho thong tong the (trong chuong trinh giao duc pho thong moi) [The Draft of General Education Curriculum (in the New Education Curriculum)]. Hanoi.

MoET (2015b). Dap an de thi THPT quoc gia 2015 [The Standard Answers of the National Graduation Exams at Vietnamese High Schools]. http://tin.tuyensinh247.com/dap-an-de-thi-thpt-quoc-gia-2015-chinh-thuc-bo-gddt-c28a23226.html

Moran, S. (2010). Creative in School. In K. Littleton, C. Wood, \& J. K. Staarman (Eds.), International Handbook of Psychology in Education (pp. 319-359). Bingley: Emerald Group Publishing Limited.

Nadjafikhaha, M., Yaftianb, N., \& Bakhshalizadehc, S. (2012). Mathematical Creativity: Some Definitions and Characteristics. Procedia-Social and Behavioral Sciences, 31, 285-291. http://dx.doi.org/10.1016/j.sbspro.2011.12.056

National Advisory Committee on Creative and Cultural Education (NACCCE) (1999). All Our Futures: Creativity, Culture and Education. London: DfES.

National Council of Educational Research and Training (1998). National Curriculum for Elementary and Secondary Education. A Framework. New Delhi.

National Endowment for the Arts (2010). Art Works for America, Strategic Plan, FY 2012-2016. https://www.arts.gov/sites/default/files/NEAStrategicPlan2012-2016_0.pdf

Neira, J. A. P., \& Soto, I. R. S. (2013). Creativity and Physics Learning as Product of the Intervention with Conceptual Maps and Gowin's V Diagram. Creative Education, 4, 13-20. http://dx.doi.org/10.4236/ce.2013.412A1003

Northcott, B., Miliszewska, I., \& Dakich, E. (2007). ICT for (I)nspiring (C)reative (T)hinking. In ICT: Providing Choices for Learners and Learning, ascilite Singapore Proceedings (pp.761-768). Singapore: Ascilite.

Okpara, O. F. (2007). The Value of Creativity and Innovation in Entrepreneurship. Journal of Asia Entrepreneurship and Sustainability, 3. http://www.asiaentrepreneurshipjournal.com/AJESIII2Okpara.pdf 
P21 (2007). P21’s Framework for 21st Century Learning. http://www.p21.org/our-work/p21-framework

Ramet, A. (2007). Creative Writing. UK: How to Books.

Robinson, K. (2010). Changing Education Paradigms.

https://www.ted.com/talks/ken_robinson_changing_education_paradigms

Runco, M. A., \& Jaeger, G. J. (2012). The Standard Definition of Creativity. Creativity Research Journal, 24, 92-96. http://dx.doi.org/10.1080/10400419.2012.650092

Sahlberg, P. (2009). The Role of Education in Promoting Creativity: Potential Barriers and Enabling Factors. In E. Villalba (Ed.), Measuring Creativity (pp. 337-344). Luxemburg: OPOCE.

Simons, H. (2009). Case Study Research in Practice. London: Sage.

Sorby, S. A. (1999). Developing 3-D Spatial Visualization Skills. Engineering Graphics Journal, 63, 21-32.

Starko, A. J. (2013). Creativity in the Classroom Schools of Curious Delight. New York: Routledge.

Sternberg, R. J. (1999). Handbook of Creativity. Cambridge: Cambridge University Press.

Sternberg, R. J. (2012). The Assessment of Creativity: An Investment-Based Approach. Creativity Research Journal, 24, 3-12. http://dx.doi.org/10.1080/10400419.2012.652925

Tan, A. G. (1997). What Can We Learn from a Century of Cultivating Creative Thinking in Japan? Teaching and Learning, 18, 9-18. https://repository.nie.edu.sg/bitstream/10497/387/1/TL-18-1-9.pdf

Torrance, E. P. (1979). The Search for Satori and Creativity. New York: Creative Education Foundation.

Tytler, R. (2007). Re-Imagining Science Education Engaging Students in Science for Australia’s Future. Australian Education Review, No. 51, 1-77.

Vygotsky, S. L. (2004). Imagination and Creativity in Childhood. Journal of Russian and East European Psychology, 42, 7-97. 


\section{Appendix 1. Survey Questions}

Dear Teacher,

This questionnaire is sent to you to gather data on your experiences in teaching for creativity development of your students (e.g. your understanding of creativity and teaching for creativity, teaching objectives and the use of creative tools and methods in teaching for creativity). Your feedback is highly appreciated, will be kept in confidential and used for recommending policies of teachers' professional development in the 21 Century.

Please take few minutes to answer the following questions.

Your personal information: (please tick X or fill in information)

Your gender: a) F b) M; Your age:

Your teaching subject: Qualification:

Years of teaching:

Questions

1) What do you mean by "Creativity"? Please tick $X$ in the appropriate box below or provide your own understanding.

\begin{tabular}{|c|c|c|c|}
\hline Creativity means: & Correct & Wrong & Neutral \\
\hline \multicolumn{4}{|l|}{ New inventions } \\
\hline \multicolumn{4}{|l|}{ Making a thing newer or better } \\
\hline \multicolumn{4}{|l|}{ News } \\
\hline \multicolumn{4}{|l|}{ Generating new solutions } \\
\hline \multicolumn{4}{|l|}{ Generating new ideas } \\
\hline \multicolumn{4}{|l|}{ Creating new things } \\
\hline Your own definition (if yes, please specify) & & & \\
\hline
\end{tabular}

2) Is creativity development for students important? (Please tick $\mathrm{X}$ in one variant)

a. Yes; b. No

3) What do you mean by "teaching for creativity development"? (Please tick X in a variant(s) you think appropriate)

a) Embedding students' creativity development in teaching objectives;

b) Use ICT in your teaching

c) Use active teaching methods.

d) Other (if yes, please specify)

4) Have you taught to develop your students' creativity? (Please tick X in one variant)

Yes No

5) Please explain your reasons why or why not you teach for creativity?

6) Please tick $X$ in an appropriate box for each item in the table below to indicate conditions that you think are needed for a person to be creative.

\begin{tabular}{|c|c|c|c|}
\hline Conditions for creativity & Necessary & Don't necessary & Neutral \\
\hline \multicolumn{4}{|l|}{ Having curiosity about surroundings } \\
\hline \multicolumn{4}{|l|}{ Having imaginative competence } \\
\hline \multicolumn{4}{|l|}{ Having knowledge about subjects } \\
\hline \multicolumn{4}{|c|}{ Having facilities for creative activities } \\
\hline \multicolumn{4}{|c|}{ Having encouragement environments for creativity } \\
\hline \multicolumn{4}{|c|}{ Understanding of creativity and its processes } \\
\hline \multicolumn{4}{|l|}{ Having lateral thinking } \\
\hline \multicolumn{4}{|c|}{ Having freedom for expressing creative ideas } \\
\hline & se specify) & & \\
\hline
\end{tabular}


7) Please tick $X$ in an appropriate box for each item in the table below to show us:

a) The level you know about a tool?

b) If you know a tool, please indicate how do you know about it?

c) The frequency you use a tool in your teaching?

\begin{tabular}{|c|c|c|c|c|c|c|c|c|c|}
\hline \multirow{2}{*}{ Tool } & \multicolumn{3}{|c|}{ Known level } & \multicolumn{2}{|c|}{$\begin{array}{l}\text { How do you } \\
\text { know the tool? }\end{array}$} & \multicolumn{4}{|c|}{ Frequency of Use } \\
\hline & $\begin{array}{c}\text { Well } \\
\text { known }\end{array}$ & $\begin{array}{c}\text { Heard } \\
\text { about }\end{array}$ & $\begin{array}{c}\text { Totally } \\
\text { don't know }\end{array}$ & $\begin{array}{l}\text { Was } \\
\text { trained }\end{array}$ & Self-learned & Often & Sometimes & Rarely & Never \\
\hline \multicolumn{10}{|l|}{ Mind maps } \\
\hline \multicolumn{10}{|l|}{ Brainstorming } \\
\hline \multicolumn{10}{|l|}{ SCAMPER } \\
\hline \multirow{3}{*}{\multicolumn{10}{|c|}{$\begin{array}{c}5 \text { WH question (What? Who? } \\
\text { When? Where? Why? } \\
\text { How?)? }\end{array}$}} \\
\hline & & & & & & & & & \\
\hline & & & & & & & & & \\
\hline \multicolumn{10}{|l|}{ "What if..." question } \\
\hline \multicolumn{10}{|l|}{ Six thinking hats } \\
\hline \multicolumn{10}{|l|}{ Random words } \\
\hline \multicolumn{10}{|l|}{ Blog } \\
\hline \multicolumn{10}{|l|}{ Wiki } \\
\hline \multicolumn{10}{|l|}{ Random picture } \\
\hline \multicolumn{10}{|l|}{ Internet information } \\
\hline $\begin{array}{c}\text { Other } \\
\text { (please specify if yes) }\end{array}$ & & & & & & & & & \\
\hline
\end{tabular}

Thank you for your responses!

\section{Appendix 2. Teachers' Interview Schedule and Questions}

Teacher's subject:

School name:

Address:

Date interviewing:

Contact: email: Cellphone:

Introduction: This interview aims to gain an insight into your perception of creativity and teaching for creativity after we received your answers from the survey. We will ask you some further questions based on your responses, please feel free to talk to us.

\section{Questions:}

1) In your responses to the questionnaire, you already showed us your understanding about creativity in general meaning. Could you please tell us your understanding about students' creativity in your subject?

2) Have you taught to develop your students' creativity? Why or why not?

3) Your responses in the questionnaire showed that you knew well about [names of the creative tools] and used it in your teaching.

a) Why do you use the tools [name...] in your teaching?

b) How do you use the tools [name]?

4) You stated in the questionnaire that you knew well about [names of the creative tool(s)], but you have not used the tools [names]. Why have not you used the tools [names] in your teaching?

5) Why do you think physical facilities are important for students' creativity development? 